International Symposium on Open, Distance, and e-learning (ISODEL) 2018

\title{
UTILIZING EDMODO IN PREPARING COMPUTER-BASED LEARNING AT THE SENIOR HIGH SCHOOL
}

\author{
Muzanip Alperi \\ Instructional Desainer, Lembaga Penjaminan Mutu Pendidikan Bengkulu, Kementerian \\ Pendidikan dan Kebudayaan, Jl. Zainul Arifin No. 2 Kota Bengkulu, Indonesia \\ Email : muzanip.alperi@kemdikbud.go.id
}

ABSTRACT: This study is very important because the 21st century requires ICT-based learning and Edmodo is one of the most familiar digital classes used in learning. Today's high school students are very good at using computers and the internet. The purpose of this study was to find out how the conditions of application of Edmodo class in Senior High School (SMA), explain the role of Edmodo in computer-based learning of high school students, and design the stages of applying learning with Edmodo to high school students. The research method is to use literature study and observation. The literature review used is literature in the form of books, research results related to Edmodo's digital class. Observations on the use of Edmodo in learning are carried out in schools that have implemented learning with Edmodo. Studies and theories are associated with discussing the problems that occur to find a solution. The results of this study stated that the use of Edmodo at the high school level is still lacking, so it needs to be developed considering that the computer and internet facilities are complete and the computer competency seems good. The use of Edmodo can improve the computer competence of high school students, digital literacy with computers and the internet is very supportive of learning, and Edmodo classes can be accessed wherever they are equipped with facilities. The stages of application of Edmodo are beginning with policies, outreach, facility preparation, strengthening of student computer competencies, class making and explanation, application of Edmodo class, development, evaluation and continuous planning. Keywords: Edmodo, Computer Competency, Digital Class.

\section{INTRODUCTION}

Based on the results of the 2013 curriculum learning observation by researchers with a team at the Bengkulu Senior High School, almost all teachers have not used computer-based media. Of the 20 high school teachers observed, only 2 teachers (10\%) used computers as learning media. No teacher has been observed using Edmodo digital class media. 
The use and development of computer-based learning media needs to be done by teachers to be relevant to the times. The digital age today requires teachers and students to be skilled in

using computers and the internet. One of the computer-based media that has benefited learning is Edmodo's digital class.

In 2016 researchers conducted a study of digital classroom training held by Quality Assurance Institution of Bengkulu, the results showed that trained senior high school teachers could easily use Edmodo's digital class. The results of the training conducted at senior high school teachers in the District of Buleleng Bali showed that $100 \%$ of the training participants stated that Edmodo's social media-based e-learning is very useful, this is in accordance with the application needs of eLearning obtained during the situation analysis (Pradnyana, Pradnyana,

\& Isindu, 2016). Edmodo learning can also be done anywhere. By using Edmodo learning is not bound by space and time, so students can ask questions and receive enrichment anytime and anywhere (Cahyono, 2015).

The effect of using Edmodo learning media is very good in learning, including increasing student motivation (Royani, Falahuddin, \& Testiana, 2018; Hikmawan \& Sarino, 2018), can improve learning outcomes (Yunus \& Rakib, 2016; Nurdani, 2016;) .

Computer skills of high school students need to be given a container and guided continuously. The National Examination is now computer based. With the existence of a computer-based National Examination, of course education providers and schools must provide facilities that support one of them computers and internet networks.

Computer-based learning will be very favored by students in the current millennial era. Various types of computer-based learning is growing rapidly, e-learning learning is now developing into mobile learning (Effendi \& Zhuang, 2005), when virtual universities emerge, anyone can be followed, anywhere and anytime, and will develop into a virtual school (Darmawan, 2012)

The purpose of this study was to find out how the conditions of application of Edmodo class in Senior High School, explain the role of Edmodo in computer-based learning of high school students, and design the stages of applying learning with Edmodo to high school students. 


\section{LITERATURE REVIEW}

Edmodo is one part of e-learning that has opened new horizons in education. E-learning is essentially a form of conventional learning as outlined in digital format and presented through Information Technology (Darmawan: 2012: 12-13).

According to Suryani, Setiawan \& Putria (2018), Edmodo is a global Education Network that aims to connect all students with people and learning resources needed to achieve maximum potential.

It can be said that Edmodo is a social network in the world of education and as a digital class whose purpose is to connect all students with digital learning resources.

Edmodo designed cloud-based collaboration is an application that is safe to use by teachers and students. With Edmodo, it will be easier to monitor student interactions in Edmodo Learning Environment. Provides an environment where students become more independent, without forgetting the standard of measuring student success (Rismayanti, 2016). More value from Edmodo is that parents can monitor the progress of their children's learning activities (Zakaria, 2017).

Edmodo has several benefits in learning as follows:

1. Edmodo is an efficient information sharing place for teachers and students.

2. Providing ease of communication between students with the supervision of teachers and parents.

3. In addition, Edmodo facilitates communication between teachers, students and parents of students.

4. As an appropriate means for examinations and quizzes.

5. Teachers can provide teaching materials such as questions, photos, learning videos to students easily. In addition, students can also download the teaching material

6. Facilitate the teacher in giving questions from anywhere and anytime.

7. Increase the computer and internet skills of teachers and students.

According to Dwi Kristiani (2016) Edmodo uses a design similar to Facebook, which provides a safe place for teachers and students to interact, collaborate and share content. The teacher can also send grades, material, assignments and quizzes to students. Students can ask questions, ask for additional assignments that can be made as homework and see their values and respond to teachers who have posted about their assignments or subject matter. The teacher can also make discussions / polls with a topic that has been posted for discussion among students. The teacher can distinguish and individualize learning through 
the creation of sub-groups in learning activities. After each learning period is complete, the teacher closes out the network and creates a new one for the next learning

Along with the learning that is listed above, education uses social networking sites such as Edmodo, which has offered the opportunity to be able to do combinations in "connecting with students and helping them create norms and reflecting on how different online actions will be interpreted." Edmodo gives educator opportunity offers for students in the search for experience in the use of social networks and ethical use of media and online formats.

One of the computer-based media is e-learning. Edmodo is a form of e-learning. According to Susila and Riyana (2007), e-learning is a learning system that utilizes electronic media as a tool to assist learning activities.

Electronic learning is terprogran and some are not programmed. Programmed learning is learning that is designed by the teacher to be followed by students starting from the scenario, learning process and evaluation, for example Edmodo digital class designed by the teacher and followed by students. Non-programmed learning is the search for learning materials online with no special program.

Computer-based learning media in the digital era received great attention because of its ability to help the process of understanding learning material.Menurut Daryanto (2016) pemakaian komputer dalam pembelajaran dengan tujuan:

\section{Cognitive}

Can teach concepts of rules, principles, steps, complex processes and calculations. Computers can also explain simply by combining animated visuals and audiovisuals, making them suitable for independent learning.

\section{Psychomotor}

With learning packaged in the form of games and simulations, it is very good to use to create working conditions. For example aircraft landing simulation, war simulation and so on.

\section{Affective}

If it is designed appropriately by giving a sound clip or video help that arouses feelings, attitude learning can be done using computer media. 
In other words, learning activities that are mostly related to the psychomotor realm are practice in the hall / field and practicum in the laboratory. In the practice activities there are also cognitive and affective domains, but only slightly when compared to the psychomotor domain. Psychomotor development that is passed by high school students has a specificity.

Cognitive abilities continue to develop during high school. However, however, not all cognitive changes during the high school period lead to increased potential. Sometimes some cognitive abilities deteriorate with age. Nevertheless, a number of experts believe that the decline of cognitive skills that occur especially during the final high school period can be increased again through a series of trainings.

Cognitive development in the early adult phase, Piaget's cognitive stages describe increased efficiency in acquiring new information. For example, in early adulthood there was a change from seeking knowledge to applying knowledge, applying what was already known, especially in terms of career determination and preparing to face marriage and family life.

\section{METHOD}

The literature review used is literature in the form of books, research results related to Edmodo's digital class. Observations on the use of Edmodo in learning are carried out in schools that have implemented learning with Edmodo. Studies and theories are associated with discussing the problems that occur to find a solution

The method used in this study is a literature review, namely by examining theories from books, research results, and other literature related to Edmodo. Library study is a method of collecting data by searching for information through books, the results of research and studies, and other literature that aims to form a theoretical basis (Arikunto, 2006).

The study of theory will not be separated from literature studies or literature studies because real theory can be obtained through the study or study of literature. Nazir (2005) states that literature studies or literature studies, aside from looking for secondary data sources that will support research, are also needed to find out where the research related science has developed, to where there are conclusions and generalizations that have been made so that the situation what is needed is obtained.

Searching for the source of this study is done by searching in journals and writing online, looking for sources of reading in relevant libraries and bookstores. In discussing findings from various literatures, the authors held discussions with media experts, education experts, and relevant psychologists. 
The researcher also made observations to high school level schools to conduct studies that supported the resolution of the problems faced. In addition, researchers also held discussions with colleagues and several academic experts from the University of Bengkulu.

\section{RESULT AND DISCUSSION}

\section{The application of Edmodo in high school and facilities that support it}

The application of learning media by using Edmodo's digital class in high school is still not being fully utilized. From the observation that the Mandiri Plaju Madrasah Aliah Patra, still applies conventional learning, especially in mathematics. Conventional learning referred to here is learning where the delivery of material is described by the teacher without using media and teaching aids in learning and then giving questions (assignments) to students with limited material (Agustina, Isnaini, \& Nery, 2016). From the results of observing learning in Bengkulu Province High School, no school has implemented the Digital Edmodo class. Problems faced due to the lack of teachers' ability to use digital classes. In some high schools in the region there are still limited problems with computer facilities, especially internet networks. The fact about the low utilization of edmodo-based learning media comes from the results of interviews with productive subject teachers in private Vocational Schools in Cimahi City. The low utilization of instructional media has an impact on student learning motivation that is low in the school. This can be proven from empirical data from the school, namely the attendance data of class $X$ students on productive subjects during odd semester as shown in the following graph (Hikmawan \& Sarino, 2018).

This condition is not maximal due to many factors:

1. Teacher's lack of ability

2. For remote areas, lack of computer facilities and internet networks.

3. Awareness of teachers who do not understand the importance of technological and information development.

4. Lack of support from the school management.

To implement Edmodo digital class in high school that has complete facilities, it is necessary to do socialization and planning in the high school. Because many things provide benefits when this digital class is utilized properly.

Edmodo is a digital class that can be used for free with the address www.edmodo.com. Based on the results of the survey authors, high school students (SMA) have been able to 
use computers properly. In addition, facilities in the form of computer laboratories and internet networks are available in almost all high schools in the city of Bengkulu.

Edmodo is a digital class with features that are easy to use for school-age children, making it easy to use in learning activities. Edmodo and Moodle are very suitable choices to be used as online learning media because there are many features offered in terms of optimizing learning as well as facilitating teaching and learning activities between teachers and students (Retnoningsih, 2017).

Future teacher perceptions of conventional teaching, shifting teaching styles from conventional design to digital and the possibility of implementing Edmodo to overcome learning problems faced (Mokhtar, 2016).

Edmodo and Moodle are very suitable choices to be used as online learning media because there are many features offered in terms of optimizing learning as well as facilitating teaching and learning activities between teachers and students (Retnoningsih, 2017).

Learning problem-based collaborative learning methods and dynamic web technology can be used in learning environments (Erhan and Hasan, 2017).

\section{Edmodo's role in Computer Based Learning for High School Students}

Edmodo has a number of advantages over learning without using this strategy (Tanjung D.R., 2016). The learning process in Edmodo-based E-learning becomes more dynamic and fun so that it increases motivation and independence of learning which has a large influence on student learning achievement in the learning process. The following are the benefits of using Edmodo especially for high school students:

1. The use of Edmodo can improve the computer competence of high school students,

Using edmodo means that teachers and students will be connected directly to computers and internet networks. A high school student who is accustomed to using computers and the internet will increase the computer competence of high school students. High school students will carry out the Computer-Based National Examination (UNBK), so it is very necessary to sharpen the ability to use computers. Computer and internet competencies are part of the demands of 21 st century skills for a teacher.

2. Digital literacy with computers and the internet is very supportive of learning.

In learning with Edmodo digital class, students will be given study material in the form of ebooks, presentations, quizzes, assignments, and examinations. Students can read all the sources given by the teacher. In 2013 curriculum learning, teachers and students are 
required to increase literacy which strengthens understanding of subject matter. One source of unlimited literacy is digital literacy. The literacy movement has been echoed nationally. One of the emphasized literacy is digital literacy (internet).

3. Edmodo digital class can be accessed anywhere as long as it has facilities.

From various sources that are used as references, it can be stated that Edmodo can be used as a social network as well as a digital class that is safe for students because the content and design of the class and edmodo social network are specifically for teachers, students and parents. So that the use of an Edmodo account is very beneficial for teachers and students and is very unlikely to be misused for crime. Edmodo can be used anywhere with internet network coverage. Students can communicate related to learning material at any time with teachers and fellow friends.

Edmodo is designed to make students eager to learn in a more familiar environment (Nu'man, 2014). In Edmodo teacher with students or between students can conduct online class discussions, provide polls to check student understanding, and award badges to students individually based on performance or behavior.

The learning compilation team with Edmodo (2015) explained that in terms of edmodo learning, teachers are in the midst of a strong network that connects teachers to students, administrators, parents. This network is the best surface resource in the world and tools, which provide educational building blocks of high quality edmodo using a design similar to Facebook, and provide teachers and students a safe place to connect, collaborate and share content. The teacher can also send grades, assignments and quizzes to students / students. Students can submit homework and see their values and teacher / lecturer comments may have been posted about their assignments. Teachers / lecturers can also make polls and post topics for discussion among students. The teacher can distinguish and create independent learning through the creation of sub-groups in the course. After each course period is completed, the teacher / lecturer closes, exits the network and creates a new one for the next course.

\section{The stages of applying learning with Edmodo to high school}

students The stages of application of Edmodo are beginning with

- Policy,

The headmaster with the support of all school members made a regulation that all teachers and students must have an Edmodo account. For students who experience limitations, student accounts can be made by the teacher of each class.

Every announcement, report, material and learning activity is cultivated using Edmodo account. In order to be able to be controlled, all classes held by the teacher are connected 
with the principal. So that tiered control can occur. The teacher controls the students and the principal controls the students.

The hope is that all active school members open an Edmodo account every day both at school and at home. As children are currently addicted to Facebook, we switch opium to Edmodo

- Socialization,

Providing training to all teachers, then the teacher trains all students to use edmodo.

- Facility preparation,

Internet network, computer lab, and is allowed to carry HP at certain hours or days

- Strengthening student computer competence,

Build competency is the competence to use media

- Class making and explanation,

Before starting students must be registered in advance in order to use digital classes.

- The application of Edmodo class,

The application of Edmodo class is adjusted to the scenario built by the teacher.

- Development,

The purpose of development is the development of a digital class related to the input of improving digital class media in the future.

- Continuous evaluation and planning

This beredmodo application continues to be evaluated for improvements in the following periods.

\section{CONCLUSION AND SUGGESTION}

The results of this study stated that the use of Edmodo at the high school level is still lacking, so it needs to be developed considering that the computer and internet facilities are complete 
and the computer competency seems good. The use of Edmodo can improve the computer competence of high school students, digital literacy with computers and the internet is very supportive of learning, and Edmodo classes can be accessed wherever they are equipped with facilities. The stages of application of Edmodo are beginning with policies, outreach, facility preparation, strengthening of student computer competencies, class making and explanation, application of Edmodo class, development, evaluation and continuous planning.

\section{REFERENCES}

\section{Books}

Arikunto. 2016. Prosedur Penelitian : Suatu Pendekatan Praktik . Jakarta: Rieneka Cipta.

Darmawan D . (2012). Teknologi Pembelajaran. Bandung: Remaja Rosdakarya Darmawan, Deni.2012. Teknologi Pembelajaran.Bandung:PT Remaja Rosdakarya Effendi E dan Zhuang H. (2005). E-Learning Konsep dan Aplikasi. Yogyakarta: Andi Nazir, M. 2005. Metode Penelitian. Jakarta: Ghalia Indonesia.

Suryani N, Setiawan I, dan Putria A. (2018). Media Pembelajaran Inovatif dan Pengembangannya. Bandung: Remaja Rosdakarya.

Susila R \& Riyana C (2007). Media Pembelajaran. Bandung : CV. Wacana Prima.

\section{Journals/ Proceedings/ Dissertations/ Theses}

Agustina, Isnaini M, \& Nery R. S. (2016). Pengembangan Bahan Ajar Matematika Menggunakan Edmodo Pada Materi Fungsi. Jurnal Pendidikan Matematika JPM RAFA Vol.2, No.1, September 2016

CahyonoY.D.(2015) e-learning (edmodo) sebagai media pembelajaran sejarah. Jurnal Penelitian. Volume 18, No. 2, Mei 2015, hlm. 102-112

Dwi Kristiani. 2016. PROSIDING SEMINAR NASIONAL MULTI DISIPLIN ILMU \& CALL FOR PAPERS UNISBANK (SENDI_U) KE-2 Tahun 2016 Kajian Multi Disiplin IImu dalam Erhan ÜNAL, Hasan ÇAKIR .2017. Students' Views about the Problem Based Collaborative Learning Environment Supported By Dynamic Web Technologies. Malaysian Online Journal of Educational Technology 2017. Volume 5 - Issue 2. http://mojet.net/frontend//articles/pdf/v5i2/v05i02-01pdf.pdf. diakses tanggal 16 Oktober 2017 
Hikmawan \& Sarino. (2018). PEMANFAATAN MEDIA PEMBELAJARAN BERBASIS EDMODO TERHADAP MOTIVASI BELAJAR SISWA SEKOLAH MENENGAH KEJURUAN ( The Impact of Electronic Media Base Edmodo on Student' Motivation Learning at Vocational High School). Jurnal Pendidikan Manajemen Perkantoran Vol.1_No.2_hal. 78-85_Januari 2018. http://ejournal.upi.edu/index.php/jpmanper

Mokhtar, Farha Alia. 2016. Rethinking Conventional Teaching In Language Learning And Proposing Edmodo As Intervention: A Qualitative Analysis. Malaysian Online Journal of Educational Technology. Volume 4, Issue 2. Hala 22-37.

Nurdani A. R. (2016). penggunaan media edmodo untuk meningkatkan hasil belajar siswa pada mata pelajaran dasar-dasar perhitungan survei pemetaan kelas $x$ geomatika smk $n 3$ salatiga dan smk $n 1$ kedungwuni pekalongan skripsi program studi

pendidikan teknik bangunan. Pengembangan IPTEKS untuk Mewujudkan Pembangunan Nasional Semesta Berencan (PNSB) sebagai Upaya Meningkatkan Daya Saing Global. ISBN: 978-979-3649-96-2 Unisbank Semarang, 28 Juli 2016

Nu'man AZ.2014. Efektifitas Penerapan E-Learning Model Edmodo dalam Pembelajaran. Surakarta: Jurnal ISSN : 2086-9436 Volume 7 Nomor 1 September 2014.

Pradnyana G.A, Pradnyana I.M.A, Isindu I.G.P. (2016). Pelatihan Penggunaan E-Learning Berbasis Media Sosial Edmodo Bagi Guru Sma Di Kecamatan Buleleng .Prosiding Seminar Nasional Pengabdian Kepada Masyarakat. ISBN : 978-602-6428-05-9

Retnoningsih E. 2017. Perbandingan Learning Management System Edmodo dan Moodle Dalam Pembelajaran Online. Information System for Educators and Professionals. 1

(2): $221-230$

Ririn Widyasari.(2017). Meningkatkan Aktivitas Dan Hasil Belajar Mahasiswa Dengan Mind Map Berbantuan E-Learning Melalui Edmodo. Jurnal Teknodik Jurnal Teknodik Vol. 21 No. 1, Juni 2017. DOI: http://dx.doi.org/10.32550/teknodik.v21i1.270. Ciputat. Diakses 9 november 2018. 
Royani I, Falahuddin I, Testiana G. (2018). PENGARUH MEDIA EDMODO SEBAGAI BASIS E-LEARNING TERHADAP MOTIVASI BELAJAR SISWA PADA MATA PELAJARAN IPA . Jurnal Bioilmi Vol. 4 No. 1 Edisi Januari 2018.

Tanjung D.R. (2016). Pengaruh Penggunaan E-Learning Berbasis Edmodo Terhadap Kemandirian, Motivasi, dan Hasil Belajar Pada Materi Sistem Gerak SMA Nasional Plus Cinta Budaya Medan. Tesis. Program Pascasarjana UNIMED, Medan.

Yunus M dan Rakib M. (2016) PENGEMBANGAN MEDIA PEMBELAJARAN BERBASIS ELEARNING PADA MATA PELAJARAN EKONOMI DI SMA. Jurnal Penelitian Pendidikan INSANI, Volume 19, Nomor 2, Desember 2016, hlm. 108-113

\section{Others}

Rismayanti A. 2016. Edmodo Tutorial Getting Closer With Edmodo. SEAMOLEC. Diunduh http://www.seameo.org/SEAMEOWeb2/images/stories/Training_services/OnlineTrainin g/2017/20170209_edmodo/5-Edmodo\%20Modules\%202016.pdf (Diakses pada 02 April 2017).

Gallagher,Kerry.(2015). A Guide to Creating a Collaborative Learning Environment. Retrieved July 2018 from https://www.edsurge.com/news/2015-04-30-a-guide-to-creating-acollaborative-learning-environment 